\title{
Hybrid process, electrocoagulation-biofiltration for landfill leachate treatment
}

\author{
Oumar Dia ${ }^{a}$, Patrick Drogui ${ }^{a, *}$, Gerardo Buelna ${ }^{b}$, Rino Dubé ${ }^{b}$ \\ a Institut national de la recherche scientifique (INRS-Eau Terre et Environnement), Université du Quebec, 490 rue de la Couronne, Quebec, QC G1K 9A9, Canada \\ ${ }^{\mathrm{b}}$ Centre de Recherche Industrielle du Québec (CRIQ), 333 rue Franquet, Québec, QC G1P 4C7, Canada
}

\section{A R T I C L E I N F O}

\section{Article history:}

Received 3 August 2017

Revised 25 December 2017

Accepted 9 February 2018

Available online $\mathrm{xxxx}$

\section{Keywords:}

Landfill leachate

Electrocoagulation

Biofiltration

Humic acids

Fulvic acids

Aluminum anode

\begin{abstract}
A B S T R A C T
Landfill leachates are known for their high and complex composition of organic, inorganic and microbial pollutants. As a result, it is quite challenging to treat these effluents by using only one treatment process. A combining approach is generally required to treat efficiently these wastewaters and comply with the discharge standards. In this present study, electrocoagulation (EC) and biofiltration (BF) processes were sequentially used to treat landfill leachate. EC process has been able to remove $37 \pm 2 \%$ of the initial total COD. A fractionation of organic compounds showed that EC was particularly efficient to remove insoluble COD and humic acids. In addition, other pollutants such as turbidity, true color, $\mathrm{Zn}$ and phosphorus were significantly reduced by EC with $82 \pm 2.7 \%, 60 \pm 13 \%, 95 \pm 2.6 \%$ and $82 \pm 5.5 \%$ of removal respectively. The subsequent treatment by BF process led to completely removal of ammonia pollution ( $>99 \%$ of $\mathrm{NH}_{4}$ removal) and a partial removal of dissolved organic compounds ( $42 \pm 7 \%$ of COD removal). The hybrid process $\mathrm{EC} / \mathrm{BF}$ could form the basis of a process capable of removing organic and inorganic pollutants from many refractory wastewaters (mature landfill leachates, industrial and municipal wastewaters).
\end{abstract}

(c) 2018 Elsevier Ltd. All rights reserved.

\section{Introduction}

Landfill leachate is generated after the percolation of water (rainfall, melting snow) and solid wastes moisture through a landfill. During this percolation, different types of organic, inorganic and microbial pollutants are extracted out of the biosolids and carried by the leachate (Wiszniowski et al., 2006). Hence, this later should be captured and treated properly to avoid groundwater and surrounding surface water contamination. Among other factors, the age of the landfill and the nature of the buried biosolids have the most significant impact on landfill leachate characteristics (Renou et al., 2008). In the case of sanitary landfill, the leachate can be classified into 3 groups based on the age of the landfill, "young", "intermediary" and "mature" landfill leachates (Renou et al., 2008). The "young" leachates are generally from landfill which have $<5$ years old and are known for their high concentration of biodegradable organic compounds (Renou et al., 2008). By contrast, "mature" leachates are usually from old landfill with

Abbreviations: BF, biofiltration; BFM, biofiltration media; BP, biological process; EC, electrocoagulation; ECLL, electro-coagulated landfill leachate; FA, fulvic acids; HA, humic acids; Hyl, hydrophilic compounds; $j$, current density.

* Corresponding author.

E-mail addresses: oumar.dia@ete.inrs.ca (O. Dia), patrick.drogui@ete.inrs.ca (P. Drogui), Gerardo.Buelna@criq.qc.ca (G. Buelna), Rino.Dube@criq.qc.ca (R. Dubé).
$>10$ years old. These leachates are characterized by moderate concentrations of organic matter with a high proportion of refractory compounds mainly composed of humic substances (Mandal et al., 2017).

Biological processes (BP) are traditionally used for the treatment of landfill leachate. The use of BP is mainly justified by their simplicity, a low treatment cost, and a good performance for the removal of biodegradable organic materials and nitrogen (Kurniawan et al., 2006). However, these technologies face some limits when it is come to deal with "mature" leachates with a high proportion of bio-refractory compounds (Xiao et al., 2013). To overcome this issue, BP can be coupled with other non-biological systems to increase the purification efficiency (Mandal et al., 2017). Among these combinations, electrocoagulation (EC) process could be an interesting approach to support a biological system in a treatment system. The principle of EC consists to generate coagulant agents such as $\mathrm{Al}^{3+}$ or $\mathrm{Fe}^{2+}$ by applying a current intensity between a cathode and a sacrificial anode. These coagulants can then interact with the colloids by disturbing their stability and leading to the formation of flocs capable to settle down. The main advantages of EC are a low sludge production in comparison to the chemical coagulation, a low or no chemical reagents requirement, short treatment time, and an easy automation (Drogui et al., 2007).

Depending on the treatment needs, the BP can be used as a pretreatment or posttreatment step. In our previous study, we did 
investigate the possibility to treat landfill leachate by using biofiltration (BF) as a pretreatment process followed by EC as a secondary treatment (Oumar et al., 2016). This configuration showed a very good performance in terms of COD, nitrogen, phosphorus, turbidity, and color removals. However, the main problematic related to this configuration was the electrochemical reduction of nitrate to ammonia during the EC. In fact, nitrate ions produced from the nitrification of ammonia during the BF were transformed back to ammonia during the subsequent EC treatment and raising the ammonia concentration in the treated effluent. This phenomenon of ammonia electro-production can be alleviated by using a cathode with low hydrogen overpotential such as platinum or titanium platinized (Dia et al., 2017; Dima et al., 2005). However, these materials are costly and their use in EC process might be questionable. Another way to avoid this phenomenon is to reverse the configuration by putting the EC as a pretreatment process before the biological system. Nevertheless, there are also some uncertainties regarding this configuration such as very low phosphorus concentration after the EC and the impact of the residual metallic coagulants on the biological treatment.

The main objective of this research was to investigate the technological uncertainties related to the successive use of EC and BF for mature landfill leachate treatment. To do so, the performance of each process had been evaluated in terms of COD, $\mathrm{NH}_{4}$, phosphorus and metals removal. A particular attention was paid to the organic matter by making its fractionation in order to know which organic fractions were preferentially removed by each process.

\section{Material and methods}

\subsection{The raw landfill leachate}

The landfill leachate used in this study was sampled from a municipal landfill located in the province of Québec, Canada. This landfill is operated since 2000 and receives about 25,000 tons of biosolids per year. The buried biosolids are mainly comprised of household wastes. Around $80 \mathrm{~L}$ of leachate was sampled from an unaerated storage tank where the raw landfill leachate was stocked before any treatment. The sampling operation was carried out during a sunny October 2015 day. The leachate was then sealed in polypropylene buckets and kept at $4{ }^{\circ} \mathrm{C}$ before utilization. Table 1 shows the average initial concentrations of the raw landfill leachate and the guidelines from Quebec province for leachate discharge in the environment (MDDELCC, 2009).

\subsection{EC setup}

The EC experiments were carried out in batch mode using a cylindrical reactor with a capacity of $1.5 \mathrm{~L}$ (Fig. 1). The electrodes were arranged in a concentric manner by using a cylindrical hollow as a cathode and a full cylindrical rod as an anode. The anode was made of pure aluminum metal while the cathode was in stainless steel. The inner diameter and the length of the cathode were respectively 5 and $72 \mathrm{~cm}$, representing an area of $1130 \mathrm{~cm}^{2}$. With regard to the anode, this later had a diameter and a length of 1.9 and $79.8 \mathrm{~cm}$ respectively; corresponding to an anodic surface of $476 \mathrm{~cm}^{2}$. The distance between the electrodes was $1.55 \mathrm{~cm}$. The raw landfill leachate was introduced from the top of the reactor by a conical opening and then recirculated in a closed loop by a mean of centrifugal pump. After the treatment, the leachate was withdrawn out of the reactor via a drain valve located at the bottom of the system. This drain valve was also used to sample the leachate when the system was running. The EC cell was operated under galvanostatic mode by using a DC power supplier, Xantrex XFR40-70 (Aca Tmetrix, Mississauga, ON, Canada) to apply the desired current intensity. The EC cell was cleaned by recirculating tap water in the reactor after each experiment. A more rigorous cleaning with $5 \%$ sulfuric acid was conducted after each set of five experiments. The anodic rod was mechanically polished with sandpaper before each experiment. At the end of the experiment, the effluent was naturally settled down for at least one hour before to sample the supernatant. The samples were analyzed at the same day or kept at $4{ }^{\circ} \mathrm{C}$ for later analysis.

\subsection{Biofiltration unit}

The biological treatment was performed using an aerated BF column garnished with a mixture of peat and wood chips. The PVC column was $7.6 \mathrm{~cm}$ in diameter and $70 \mathrm{~cm}$ height. The composition of the biofilter media was (from the top to the bottom), 3.12 cm (wood chips), $9.37 \mathrm{~cm}$ ( $80 \%$ of wood chips $+20 \%$ of peat), 9.37 $\mathrm{cm}$ (wood chips), $28.12 \mathrm{~cm}$ ( $80 \%$ of wood chips $+20 \%$ of peat). Note that the given percentages are expressed as volumetric percentages. The biofilter was operated in countercurrent mode, the landfill leachate was introduced at the top of the column while the air was injected from the bottom. A peristaltic pump was used to feed the biofilter with the electro-coagulated landfill leachate (ECLL). Given the low values of BOD, ammonia was chosen as the critical parameter during the biological treatment. Hence, the feeding flow rate was set at a specific value, depending to the inlet ammonia concentration, in order to respect a nitrogen load of $0.055 \mathrm{~kg}$ of $\mathrm{N}-\mathrm{NH}_{4} \mathrm{~m}^{-2} \mathrm{~d}^{-1}$. The biofilter was aerated with a compressed air at a flow rate of $0.4 \mathrm{~L} \mathrm{~min}^{-1}$ corresponding to a superficial velocity of $5.33 \mathrm{~m} \mathrm{~h}^{-1}$. The biomass acclimation was carried out using the raw landfill leachate as inoculum. The BF unit was operated at room temperature at around $22 \pm 2{ }^{\circ} \mathrm{C}$ and its clogging was controlled by measuring the inlet and outlet flow rate every four days.

\subsection{Experimental design}

After the physio-chemical characterization of the raw landfill leachate, this later was subjected to EC treatment. The objective

Table 1

Raw landfill leachate characteristics and Québec province discharge standards.

\begin{tabular}{|c|c|c|c|c|}
\hline Parameters & Units & Raw landfill leachate & Québec regulation & $\mathrm{n}^{\mathrm{a}}$ \\
\hline Total COD & $\mathrm{mg} \mathrm{L}^{-1}$ & $1619 \pm 49$ & - & 3 \\
\hline $\mathrm{BOD}_{5}$ & $\mathrm{mg} \mathrm{L}^{-1}$ & 460 & 65 & 1 \\
\hline $\mathrm{BOD} / \mathrm{COD}$ & - & 0.29 & - & 1 \\
\hline Conductivity & $\mathrm{mS} \mathrm{cm}-1$ & 5.29 & - & 1 \\
\hline $\mathrm{pH}$ & - & $7.83 \pm 0.17$ & $6-9.5$ & 4 \\
\hline Alkalinity & $\mathrm{mg} \mathrm{CaCO} \mathrm{L}^{-1}$ & $4301 \pm 1067$ & - & 3 \\
\hline Turbidity & NTU & $178.75 \pm 54$ & - & 4 \\
\hline $\mathrm{N}-\mathrm{NH}_{4}$ & $\mathrm{mg} \mathrm{L}^{-1}$ & $653 \pm 38$ & 10 & 4 \\
\hline $\mathrm{P}-\mathrm{t}$ & $\mathrm{mg} \mathrm{L}^{-1}$ & $4.89 \pm 0.39$ & - & 4 \\
\hline $\mathrm{Zn}$ & $\mathrm{mg} \mathrm{L}^{-1}$ & $1.46 \pm 0.06$ & 0.07 & 4 \\
\hline $\mathrm{Fe}$ & $\mathrm{mg} \mathrm{L}^{-1}$ & $24.74 \pm 8.7$ & - & 4 \\
\hline
\end{tabular}

a Number of analysis. 


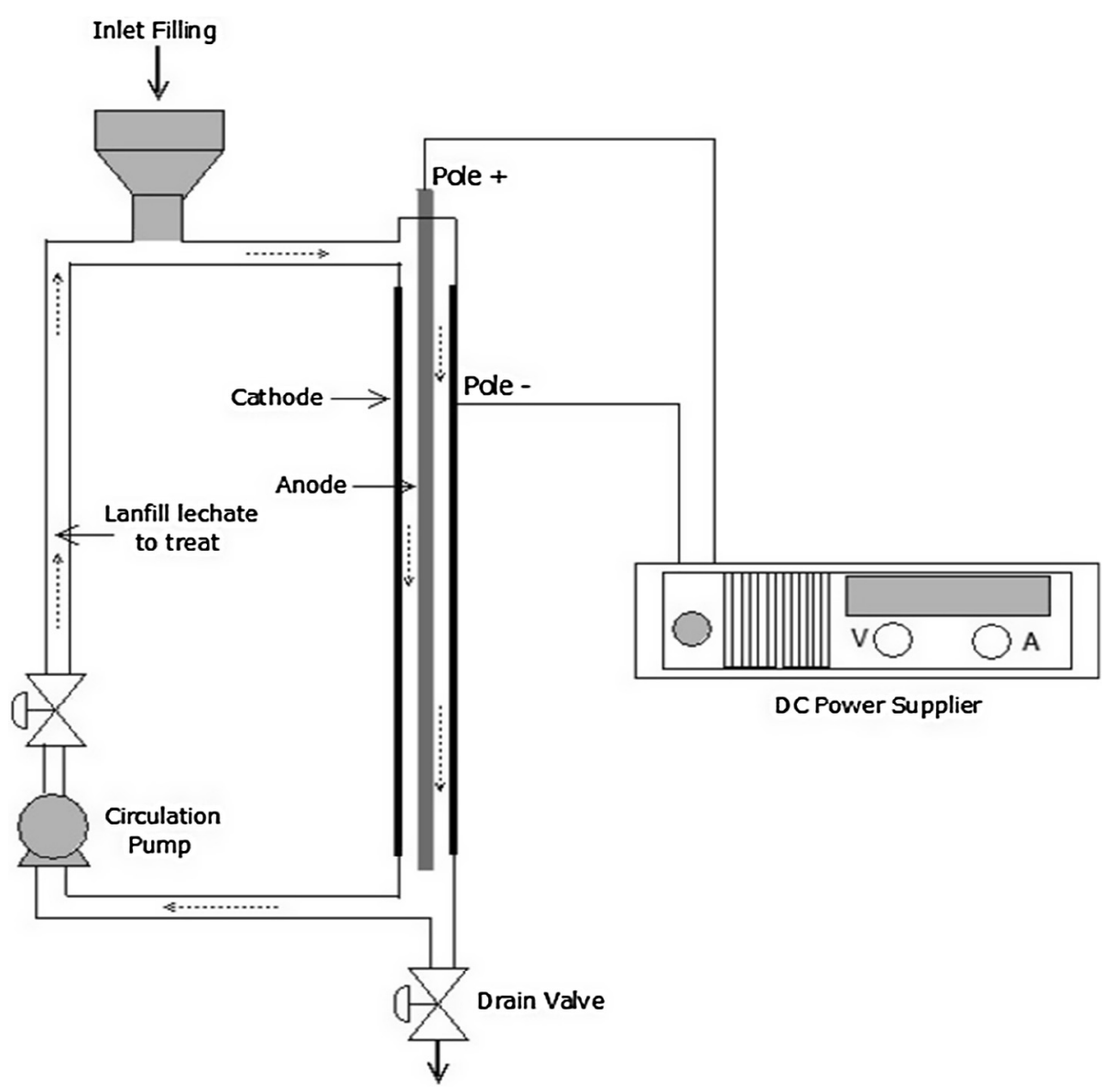

Fig. 1. Electrocoagulation set-up.

was to determine the best conditions in terms of current density and treatment time. Thus, the influence of different current densities $\left(3,5,8,10\right.$ and $\left.15 \mathrm{~mA} / \mathrm{cm}^{2}\right)$ and treatment time $(5,10,15,20$ and $30 \mathrm{~min}$ ) was tested on the COD removal. After finding the best EC operating conditions for raw landfill leachate treatment, duplicate experiments were conducted using these conditions. In addition to COD, others pollutants such as TOC, nitrogen, phosphorus, alkalinity, color and metals were analyzed as well. Thereafter, at the end of 40 days of acclimation with the raw landfill leachate, the biofiltration unit was then fed with the electro-coagulated landfill leachate. The aerated biofilter was operated continuously during 120 days with an average flow rate of $365 \pm 0.4 \mathrm{~mL} \mathrm{~d}^{-1}$. In order to assess to performance of the biofiltration treatment, samples were taken twice a week from the outlet of the biofilter column. Different types of pollutants such as COD, TOC, $\mathrm{NH}_{4}, \mathrm{NO}_{3}$, phosphorus, color, turbidity, alkalinity and metals were carried out on these samples. The removal percentages and the initial and final concentrations given in this manuscript are average values obtained during the operating period with the associated standard deviations.

\subsection{Analytical methods}

All the reagents used were analytical grade with at least $97 \%$ purity. The Chemical Oxygen Demand (COD) was measured using the colorimetric method (closed reflux) (APHA, 1998). Ammonia $\left(\mathrm{NH}_{4}^{+}\right)$and nitrate $\left(\mathrm{NO}_{3}^{-}\right)$were respectively measured by the salicylate and atrazine methods approved by USEPA (USEPA, 1979a, 1979b). BOD 5 samples were frozen and sent to an accredited external laboratory (AGAT laboratoires, Québec, Canada) and the analy- sis was performed using an electrometric method (APHA, 2012). The $\mathrm{pH}$ was measured with a pH meter (Accumet Excel XL25, Fisher Scientific Co) connected to a Cole-Palmer double junction electrode $(\mathrm{Ag} / \mathrm{AgCl}$ reference). The conductivity was determined using a Mettler Toledo conductivity meter (S230 SevenCompact ${ }^{\mathrm{TM}}$ Conductivity,) connected to a Mettler Toledo Inlab ${ }^{\circledR} 731-2 \mathrm{~m}$ conductivity electrode. A $2100 \mathrm{~N} \mathrm{HACH}$ turbidity meter was used to measure the turbidity. The total alkalinity was determined by a colorimetric titration using a $0.02 \mathrm{~N}$ sulfuric acid and methylorange as titrating agent and color indicator respectively. The true color of the samples was analyzed according to the platinumcobalt method (APHA, 2005). To avoid any interference with the suspended particles, samples were centrifuged at 15,000g during 15 min before color measurement. Metallic ions, including phosphorus, were measured using a mass spectrophotometry technique (ICP Optical Emission Spectrometer, VARIAN 725-ES). Before the metals analysis, samples were digested at $95^{\circ} \mathrm{C}$ for two hours in a mixture of nitric acid $(10 \% \mathrm{v} / \mathrm{v})$ and hydrogen peroxide $(15 \% \mathrm{v} /$ v). Total Organic Carbon (TOC) was estimated using a Shimadzu TOC 5000A analyzer (Shimadzu Scientific Instruments Inc).

The organic matter $(\mathrm{OM})$ was fractionated based on the method described by Van Zomeren and Comans (2007). Fig. 2 shows the different step of the OM fractionation. The OM was separated into three groups, humic acids (HA), fulvic acids (FA) and hydrophilic compounds ( $\mathrm{Hyl}$ ). The HA fraction was extracted by centrifugation after precipitation under $\mathrm{pH}<2$. The supernatant (FA and Hyl) was then mixed with a non-ionic and slightly polar resin (SupeliteTM DAX-8, Sigma-Aldrich Co) in order to adsorb the FA onto the resin surface while the Hyl fraction remained in the supernatant. After separating the resin from the slurry, the FA was desorbed using a 


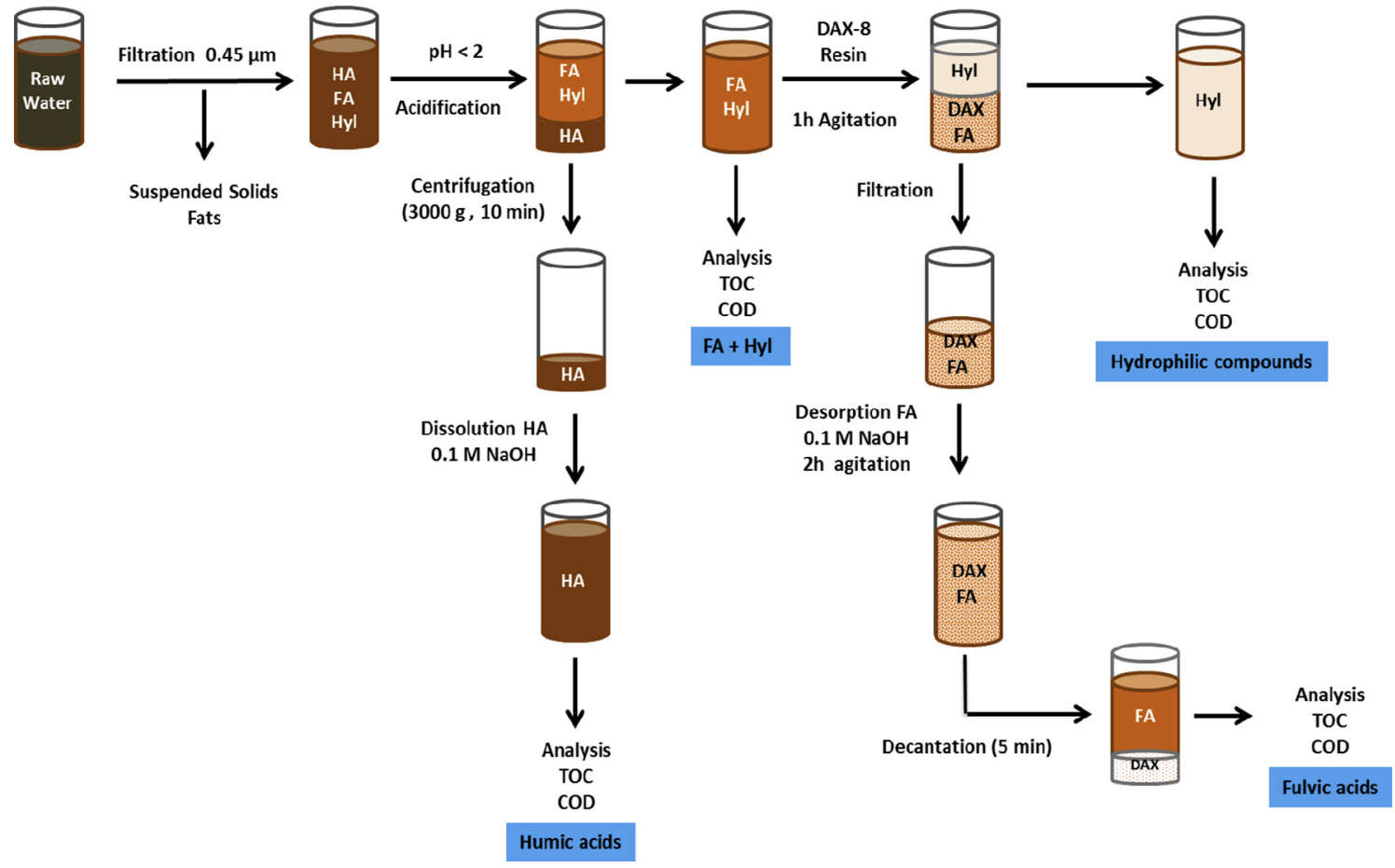

Fig. 2. Different steps organic matter fractionation.

$0.1 \mathrm{~N}$ sodium hydroxide solution. The experiments were conducted in duplicate and COD as well as TOC analysis were performed on each organic fraction.

\section{Results and discussion}

\subsection{Electrocoagulation of raw landfill leachate}

\subsubsection{Influence of current density and treatment time}

Current intensity and treatment time are the most important parameters of EC process. These parameters define the amount of coagulant $\left(\mathrm{Al}^{3+}\right)$ introduced in the reactor. In order to determine the best conditions for COD removal in terms of current density and treatment time, different values of these parameters were applied on the raw landfill leachate. The obtained results are presented in Fig. 3. From this figure, it can be seen that, for the low current densities (3-5 $\mathrm{mA} \mathrm{cm}^{-2}$ ), the COD elimination increased when the current density and the treatment time increased. However, no significant COD removal was recorded when the current density was increased in the range of $5-15 \mathrm{~mA} \mathrm{~cm}^{-2}$. Nonetheless, a current density of $8 \mathrm{~mA} \mathrm{~cm}{ }^{-2}$ and a treatment time of $20 \mathrm{~min}$ had been chosen as the best conditions for COD removal. This choice was justified by the lowest residual COD concentration recorded.

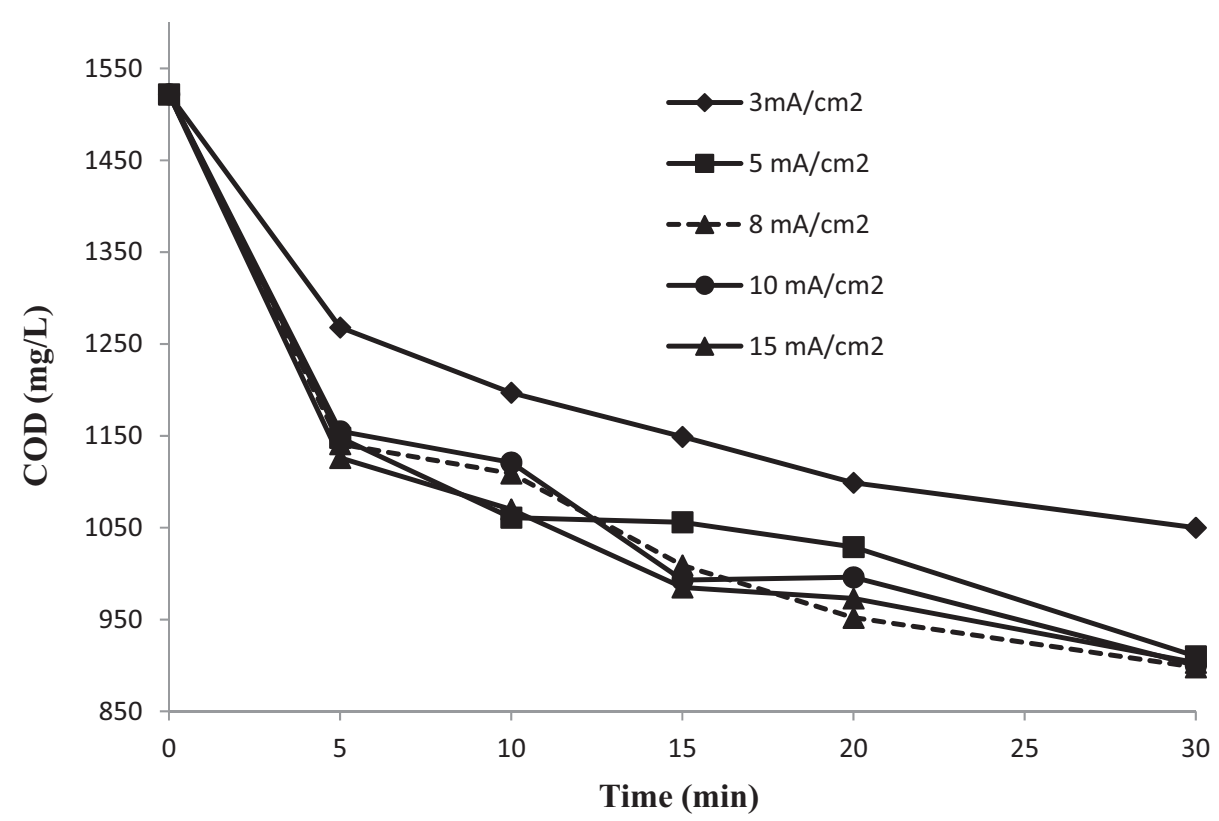

Fig. 3. Influence of current densities and treatment time on COD removal. 
The concentration of COD continued to decrease slowly after 20 min of treatment. A treatment time of 20 min was selected in order to minimize the energy consumption. Under these conditions, $37 \pm$ $2 \%$ of COD was removed. The corresponding amount of electrical charge and theoretical dissolved aluminum were 3040 A.s L ${ }^{-1}$ and $0.28 \mathrm{~g}$ of $\mathrm{Al} \mathrm{L}^{-1}$, respectively. It is worth noting that the most important part of the total COD removal (82\%) was achieved within the first 15 min of the experiment. This kinetic behavior could be explained by the presence of some organic fractions that were preferentially removed by the EC process than others. A fractionation of the organic matter was conducted before and after EC in order to assess the efficiency of EC process on each organic fraction.

\subsubsection{Dissolved organic matter fractionation}

In order to investigate the efficiency of the EC process for different organic fractions, the landfill leachate was fractioned into three groups based on their polarity properties (HA, FA and Hyl). The fractionation was carried out before and after EC treatment. TOC and COD measurements were carried out for different fractions. The results for TOC and COD are presented in Figs. 4 and 5 respectively. The total dissolved TOC of raw landfill leachate was comprised of $5.3 \%$ of $\mathrm{HA}, 36.0 \pm 0.9 \%$ of $\mathrm{Hyl}$ and, $45.4 \pm 0.6 \%$ of FA (Fig. 4). After EC treatment, only $15.1 \%$ of TOC was removed. Even though the HA fraction represented a small percentage of TOC (5\%), it was effectively removed by EC $(71.3 \pm 0.8 \%$ of HA). However, Hyl and FA compounds were not effectively removed. Only $4.4 \pm 1.1 \%$ of Hyl and $11.9 \pm 1.9 \%$ FA were respectively removed. This discrepancy in removing HA, FA and Hyl compounds was reported by some authors while using EC or chemical coagulation for the treatment of effluents containing high concentration of humic materials

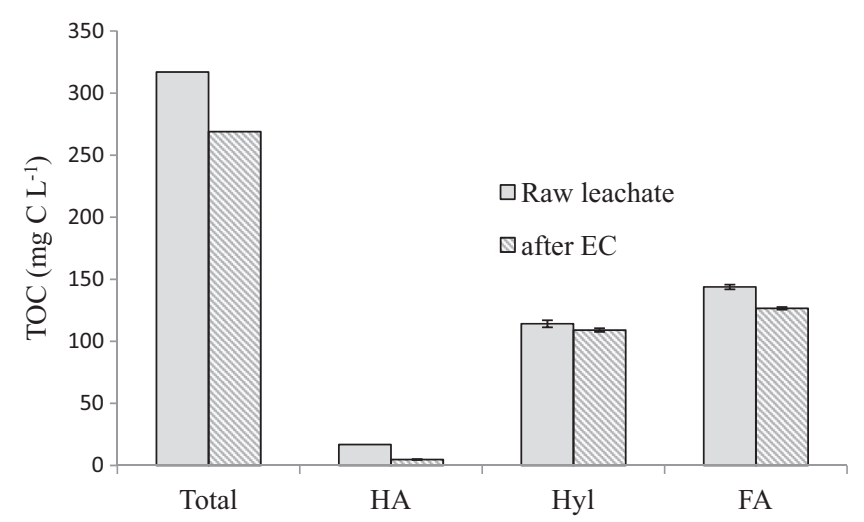

Fig. 4. TOC of different organic fractions before and after EC, Conditions, Anode $=\mathrm{Al}$ $j=8 \mathrm{~mA} \mathrm{~cm}^{-2}$ and $\mathrm{t}=20 \mathrm{~min}$.

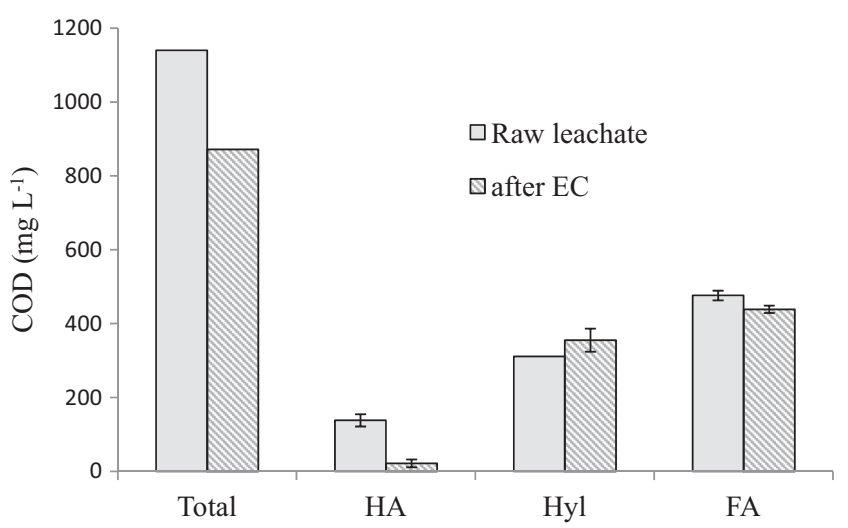

Fig. 5. COD of different organic fractions before and after EC, Conditions, Anode = $\mathrm{Al}, j=8 \mathrm{~mA} \mathrm{~cm}^{-2}$ and $\mathrm{t}=20 \mathrm{~min}$.
(Hall and Packham, 1965; Labanowski et al., 2010; Wu et al., 2011). The relatively high removal rate of humic acids could be explained by the fact that this organic fraction presents high molecular weights (10-100 KDa) (Stevenson, 1994) and negative surface charges that can react and co-precipitate with positive charges of metallic hydroxides formed during coagulation process. On the other hand, Hyl and FA compounds having lower molecular weights (<500 Da for Hyl and 1-10 KDa for HA) showed less interactions with the metallic hydroxides and tend to remain in solution.

The COD analysis of the three organic fractions is shown in Fig. 5. The raw landfill leachate COD was comprised of $12.1 \pm 1.5$ $\%$ of HA, $27.3 \%$ of Hyl and $41.8 \pm 1.1 \%$ of FA. These proportions were slightly different with those obtained with TOC measurements. For example, the HA fraction had increased by $6 \%$, whereas Hyl fraction decreased by $7.7 \%$ in comparison with TOC percentages. This could be explained by the difference of molecular structure between these two organic fractions. In fact, HA molecular structure contains a limited amount of oxygen and many aromatic rings (Huo et al., 2008). Hence, more chemical oxidants were required to oxidize these molecules and this led to the increase of COD. By contrast, the Hyl fraction, comprised of small molecular weight compounds, is easier to oxidize. According to Fig. 5, the overall removal of dissolved COD was $23.5 \%$. This was mainly attributed to HA removal ( $83.6 \pm 9.6 \%$ of HA removed), a small fraction of FA ( $7.8 \pm 4.6 \%$ of HA removed) and probably, the hydrophobic compounds which were not take account in this study.

It is worth underlining that the removal of dissolved COD (23.5\%) was quite lower than the total COD removal $(37 \pm 2 \%)$ (Fig. 3). This difference can be attributed to the insoluble COD which was efficiently removed during EC treatment. This insoluble organic matter was mainly comprised of humin which is the humic substances fraction insoluble in water at any pH. Overall, it can be concluded that the HA fraction and the insoluble organic matter were preferentially removed during EC treatment of raw landfill leachate. Other organic fractions such as FA and Hyl compounds were poorly removed.

\subsubsection{Performances of EC for other pollutants}

Table 2 summarizes the performances of EC for other pollutants removals (turbidity, color, phosphorus, nitrogen, alkalinity and metals) under the best operating conditions $\left(j=8 \mathrm{~mA} \mathrm{~cm}^{-2}\right.$ and $\mathrm{t}$ $=20 \mathrm{~min}$ ). It is important to mention that the values given in this table were the average values obtained from the analysis of electro-coagulated landfill leachate (ECLL). It can be seen that the $\mathrm{NH}_{4}$ removal was not significant. This was expected because it is well known that EC has low efficiency for ammonia removal. Other studies have also reported low ammonia removal using EC process to treat landfill leachate (Bouhezila et al., 2011; Ilhan et al., 2008; Poveda et al., 2016). Turbidity, color, and metals were effectively

Table 2

Performances of EC for the treatment of raw landfill leachate. Conditions, Anode $=\mathrm{Al}$, $j=8 \mathrm{~mA} \mathrm{~cm}^{-2}$ and $\mathrm{t}=20 \mathrm{~min}$

\begin{tabular}{lllll}
\hline Pollutants & Units & Before EC & After EC & Removal \\
\hline $\mathrm{COD}$ & $\mathrm{mg} \mathrm{L}^{-1}$ & $1619 \pm 49$ & $1018 \pm 94$ & $37 \pm 2 \%$ \\
$\mathrm{TOC}$ & $\mathrm{mg} \mathrm{L}^{-1}$ & $317 \pm 0$ & $269 \pm 0$ & $15 \pm 0 \%$ \\
$\mathrm{~N}-\mathrm{NH}_{4}$ & $\mathrm{mg} \mathrm{L}^{-1}$ & $653 \pm 38$ & $610 \pm 49$ & $6 \pm 8.7 \%$ \\
Color & $\mathrm{TCU}$ & $1620 \pm 397$ & $644 \pm 57$ & $60 \pm 13 \%$ \\
Alkalinity & $\mathrm{mg} \mathrm{CaCO}_{3} \mathrm{~L}^{-1}$ & $4301 \pm 1067$ & $3606 \pm 600$ & $16 \pm 9.9 \%$ \\
Turbidity & $\mathrm{NTU}$ & $178.75 \pm 54$ & $32 \pm 8.8$ & $82 \pm 2.7 \%$ \\
pH & - & $7.83 \pm 0.17$ & $8.42 \pm 0.24$ & - \\
Phosphorus & $\mathrm{mg} \mathrm{L}^{-1}$ & $4.89 \pm 0.39$ & $0.88 \pm 0.27$ & $82 \pm 5.5 \%$ \\
Aluminum & $\mathrm{mg} \mathrm{L}^{-1}$ & $0.64 \pm 0.09$ & $1.25 \pm 0.8$ & $-26 \pm 23 \%$ \\
Zinc & $\mathrm{mg} \mathrm{L}^{-1}$ & $1.46 \pm 0.06$ & $0.07 \pm 0.05$ & $95 \pm 2.6 \%$ \\
Iron & $\mathrm{mg} \mathrm{L}^{-1}$ & $24.7 \pm 8.7$ & $1.22 \pm 0.37$ & $95 \pm 2.3 \%$ \\
\hline
\end{tabular}


removed after EC treatment. $60 \pm 13 \%$ of true color was removed and this was probably due humic acids removal. In fact, humic acids have a high coloring capacity in spite of its low portion in raw landfill leachates. Among other metals, zinc and iron were efficiently removed $(95 \pm 2.6 \%$ of $\mathrm{Zn}$ removed and $95 \pm 2.3 \%$ of $\mathrm{Fe}$ removed). The good removal of metals by EC process could be attributed to precipitation, co-precipitation and cathodic electrodeposition (Drogui et al., 2007). However, aluminum ions concentration increased after the treatment because of the use of aluminum as sacrificial anode. Finally, the total phosphorus concentration was reduced by $82 \pm 5.5 \%$. This can be explained by the fact that phosphorus precipitated out with $\mathrm{Al}^{3+}$ and the particles complexes of $\mathrm{Al}_{3}\left(\mathrm{PO}_{4}\right)_{2}$ were removed from solution during solid/liquid separation. In fact, the particles complexes of $\mathrm{Fe}_{3}\left(\mathrm{PO}_{4}\right)_{2}$ remained in metallic sludge residues during settling of electrocoagulated landfill leachate (Smoczyński et al., 2014).

\subsection{Biofiltration}

After an acclimation period of 40 days, the biofiltration unit was fed with electro-coagulated landfill leachate (ECLL) obtained previously. In order to respect the nitrogen load $\left(0.055 \mathrm{~kg} \mathrm{~N}-\mathrm{NH}_{4} \cdot \mathrm{m}^{-2}\right.$. $\mathrm{d}^{-1}$ ), the BF unit was operated, during 120 days, with an inlet average flow rate of $365 \mathrm{~mL} \mathrm{~d}^{-1}$.

\subsubsection{Organic matter removal}

The performances of the biological treatment in terms of COD removal are shown in Fig. 6. An average COD removal of $42 \pm 7 \%$ was recorded. By comparison, $\mathrm{BOD}_{5}$ was totally removed after the biological treatment (data no shown). The relatively low COD removal can be explained by the presence of refractory organic matter in the ECLL. In fact, the FA and Hyl compounds contained in ECLL represented respectively $47 \pm 0.4 \%$ and $40 \pm 0.5 \%$ of TOC. After the treatment, $30.4 \pm 1.3 \%$ and $49 \pm 3.3 \%$ of $\mathrm{TOC}_{\mathrm{FA}}$ and $\mathrm{TOC}_{\mathrm{Hyl}}$ were respectively removed (Fig. 7). This means that the Hyl fraction having smaller molecular weight than FA fraction was preferentially removed during BF treatment. Similar observations were reported by Liu et al. (2015) using a Sequencing Batch Reactor (SBR) to treat landfill leachate pretreated by Fenton process. Huo et al. (2009) also observed a good removal rate of Hyl fraction,

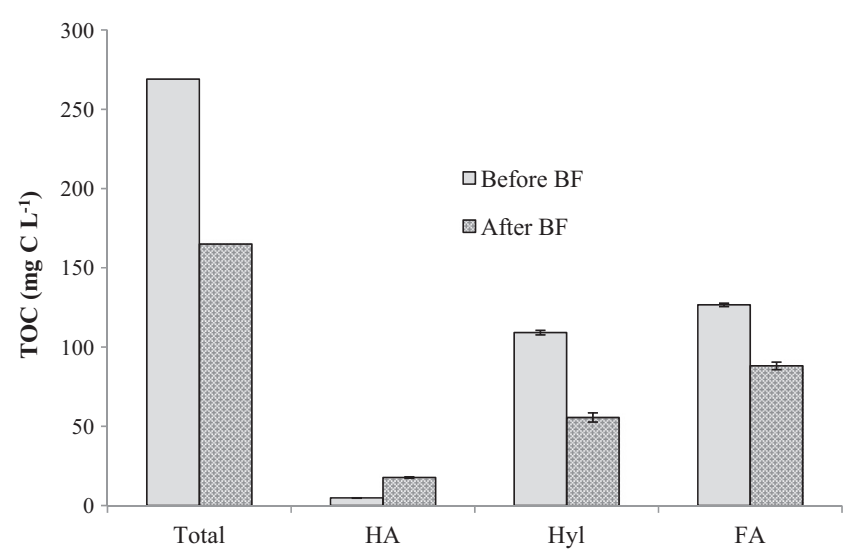

Fig. 7. Fractionation of the dissolved organic matter before and after biofiltration of the electro-coagulated landfill leachate. Conditions, Hydraulic load $=0.08 \mathrm{~m}^{3} \cdot \mathrm{m}^{-2}$. $\mathrm{d}^{-1}$, temperature $=22^{\circ} \mathrm{C}$, air flowrate $=0.4 \mathrm{~L} \mathrm{~min}^{-1}$.

whereas humic substances (HA and FA) were not significantly removed after biological treatment of landfill leachate. However, in this study, an increase of HA fraction was recorded after biofiltration treatment. This increase was likely caused by the leaching of HA from the filtration media that was comprised of a mixture of peat and wood chips.

\subsubsection{Ammonia removal}

As mentioned earlier, the removal of ammonia was very low during the electrochemical treatment. So, the main challenge of the biological treatment was to treat efficiently the ammonia pollution. The $\mathrm{BF}$ column was fed with an inlet average flow rate of $365 \mathrm{~mL} \mathrm{~d}^{-1}$ in order to respect the nitrogen load $\left(0.05 \mathrm{~kg} \mathrm{~N}-\mathrm{NH}_{4}\right.$ $\mathrm{m}^{-2} \mathrm{~d}^{-1}$ ). The variations of nitrogen forms during the biological treatment are shown in Fig. 8. It can be seen that the ammonia was almost completely removed after BF treatment. The average of residual ammonia concentration recorded at the outlet was 1.8 $4 \pm 1.7 \mathrm{mg} \mathrm{N} \mathrm{L}^{-1}$ that was far below the standard value set by the

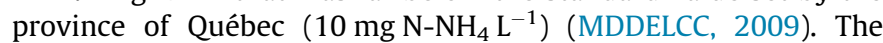
residual nitrate concentrations in the $\mathrm{BF}$ effluent were also mea-

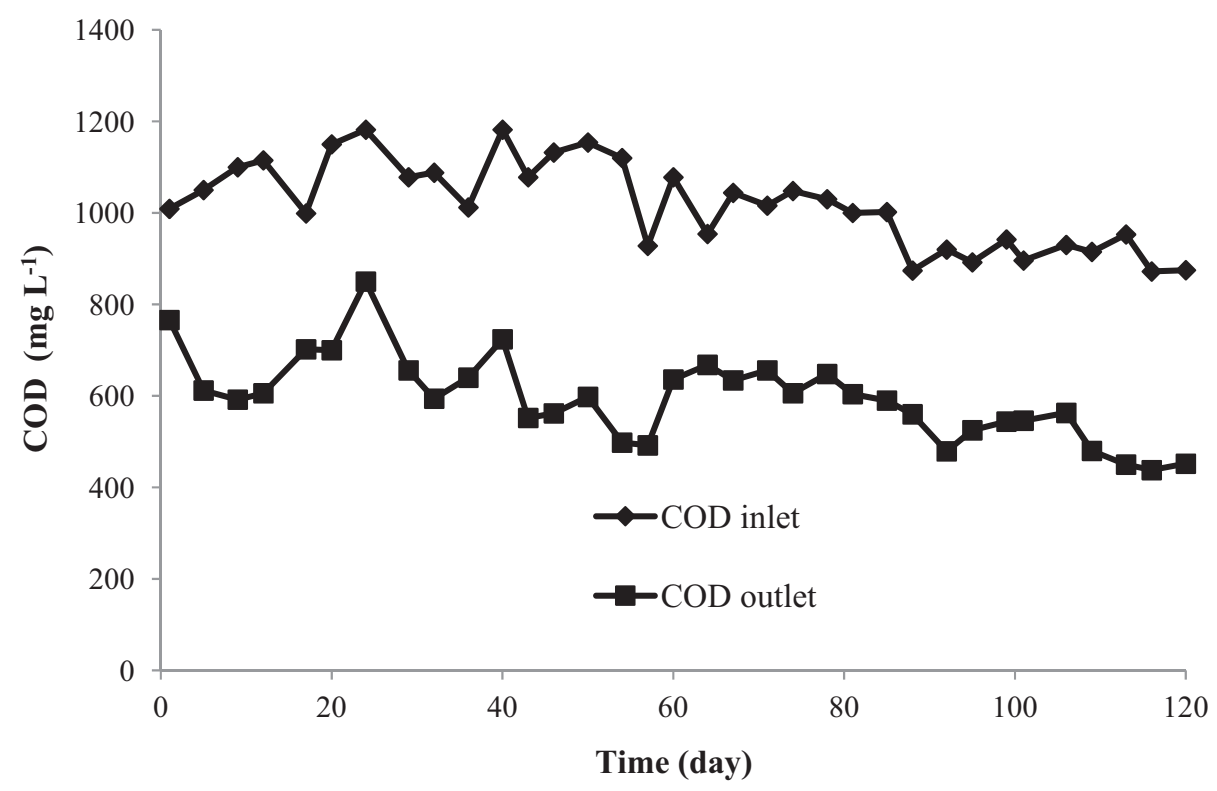

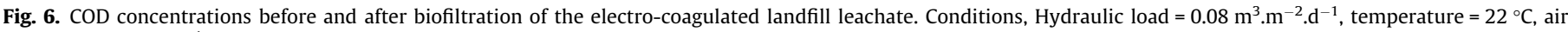
flowrate $=0.4 \mathrm{~L} \mathrm{~min}^{-1}$. 


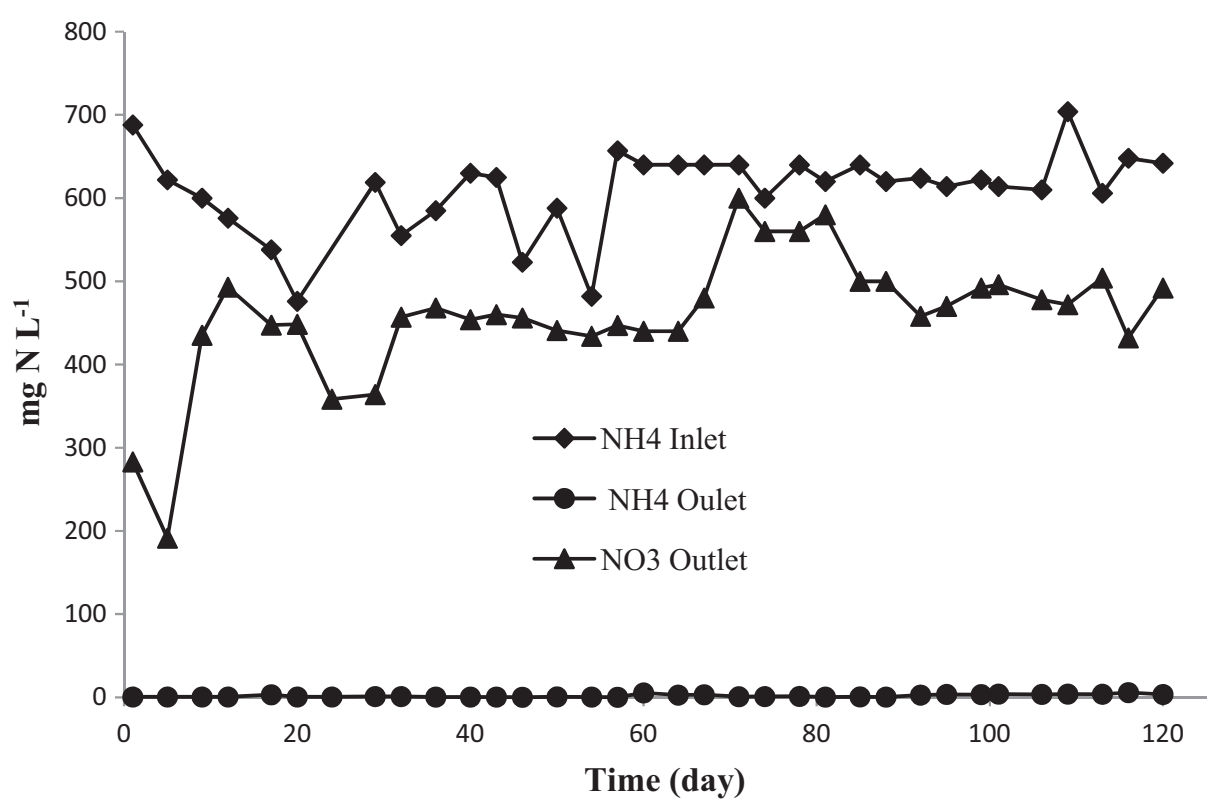

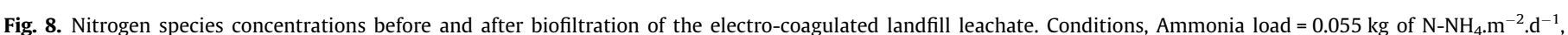
temperature $=22^{\circ} \mathrm{C}$, air flowrate $=0.4 \mathrm{~L} \mathrm{~min}^{-1}$.

sured. A percentage of $78 \pm 14 \%$ of ammonia was transformed into nitrate. It is worth noting that the nitrate concentration in the affluent was negligible. These results showed that nitrification was the main mechanism for ammonia removal in the biofilter. However, other biological and physico-chemical phenomena such as $\mathrm{NH}_{3}$ stripping, assimilation, denitrification, and adsorption might also occur in biofilter column (Garzón-Zúñiga et al., 2005).

The nitrification process was very efficient in spite of low phosphorus concentration and the significant amount of residual aluminum ions obtained after the EC treatment. Given the sensitivity of the nitrifying bacteria, there were some concerns about the inhibition of the nitrification process caused by these critical pollutants. With respect to phosphorus, the suitable dose required for the microorganisms is a controversial subject. The traditional ratio C/N/P, 100/5/1 is generally accepted for a suitable biological treatment. However, several authors reported good nitrogen removal rates in spite of a phosphorus deficiency in the affluent (Aubry, 2008; Nordeidet et al., 1994; Philips et al., 2003; Vanhooren, 2002). Vanhooren (2002) explained the low phosphorus requirement by a possible recycling of phosphorus inside the biofilm from the biomass decay. Regarding the effect of the residual aluminum, no negative impact on the nitrifying bacteria had been found. This was not consistent with some studies that argued that residual aluminum ions from chemical coagulation had negative impact on the biological treatment (Iversen et al., 2009; Lees et al., 2001; Snyman et al., 1996). In fact, metals ions can form bond and inactive complexes with some bacteria enzymes and induce an inhibition of their biological functions (Lees et al., 2001). Likewise, it had been reported that microorganisms are more sensitive to metal toxicity when these metals are in the form of free ion (Tyagi and Couillard, 1988). By contrast, the toxicity of metals decreases when they are chelated by some organic ligands such as humic substances (Koukal et al., 2003). This can explain the insignificant impact of metal on nitrification process since the landfill leachate used in this study contained significant amount of humic substances known for their excellent chelating capacity.

\subsubsection{Performance of $B F$ for other pollutants}

Table 3 summarizes the performance of the biological treatment for the other pollutants. The very low BOD concentration at the outlet indicates that all the biodegradable organic matter was removed. High alkalinity removal $(92 \pm 6 \%)$ was related to the use of the inorganic carbon by the autotroph nitrifying bacteria during the nitrification process. The true color had increased by $34 \%$ after the treatment; this was probably linked to the leaching of humic acids from wood peat-based media. Despite an increase of residual aluminum after the EC, this metal was effectively removed from $\mathrm{BF}$ effluent (>65\% of $\mathrm{Al}$ was removed).

Iron was slightly removed from the $\mathrm{BF}$ influent with a removal rate of $14 \%$. However, against all odds, the average concentration of phosphorus and zinc recorded at the outlet of BF process were higher than those measured at the inlet of BF process. The total phosphorus concentration had slightly increased by $17 \%$, while the residual zinc concentration increased was six times higher than that measured at the inlet of BF process. The increase of $\mathrm{Zn}$ was alarming because this metal is used by the Québec province regulation as indicator of metals pollution. In order to understand the reason of such increase in $\mathrm{Zn}$ concentration, further investigation had been performed focusing on the biofiltration media (BFM) components. $\mathrm{Zn}$ from the mixture of peat and wood chips were then extracted by acid leaching and analyzed. It had been found that the $\mathrm{Zn}$ concentration in the BFM was higher after utilization

Table 3

Performances of the biofiltration treatment, Ammonia load $=0.055 \mathrm{~kg}$ of N-NH $4 \cdot \mathrm{m}^{-2}$. $\mathrm{d}^{-1}$, Hydraulic load $=0.08 \mathrm{~m}^{3} \cdot \mathrm{m}^{-2} \cdot \mathrm{d}^{-1}$, temperature $=22^{\circ} \mathrm{C}$, air flowrate $=5 \mathrm{~L} \mathrm{~min}^{-1}$.

\begin{tabular}{lllll}
\hline Pollutants & Units & BF Inlet & BF Outlet & Removal \\
\hline COD & $\mathrm{mg} \mathrm{L}^{-1}$ & $1018 \pm 94$ & $595 \pm 93$ & $42 \pm 7 \%$ \\
BOD $_{5}$ & $\mathrm{mg} \mathrm{L}^{-1}$ & 150 & $<5$ & $>97 \%$ \\
$\mathrm{TOC}$ & $\mathrm{mg} \mathrm{L}^{-1}$ & 269 & 165 & $37 \%$ \\
$\mathrm{~N}-\mathrm{NH}_{4}$ & $\mathrm{mg} \mathrm{L}^{-1}$ & $610 \pm 49$ & $1.84 \pm 1.7$ & $>99 \%$ \\
$\mathrm{~N}-\mathrm{NO}_{3}$ & $\mathrm{mg} \mathrm{L}^{-1}$ & $<1$ & $462 \pm$ & - \\
Color & $\mathrm{TCU}$ & $644 \pm 57$ & $851 \pm 127$ & $-34 \pm 26 \%$ \\
Alkalinity & $\mathrm{mg} \mathrm{CaCO}_{3} \mathrm{~L}^{-1}$ & $3606 \pm 600$ & $289 \pm 71$ & $92 \pm 6 \%$ \\
Turbidity & $\mathrm{NTU}$ & $32 \pm 8.8$ & $8.1 \pm 5.3$ & $74 \pm 15 \%$ \\
pH & - & $8.42 \pm 0.24$ & $8.26 \pm 0.31$ & - \\
Phosphorus & $\mathrm{mg} \mathrm{L}^{-1}$ & $0.88 \pm 0.27$ & $1.03 \pm 0.28$ & $-34 \pm 87 \%$ \\
Aluminum & $\mathrm{mg} \mathrm{L}^{-1}$ & $1.25 \pm 0.8$ & $0.39 \pm 0.2$ & $66 \pm 27 \%$ \\
Zinc & $\mathrm{mg} \mathrm{L}^{-1}$ & $0.07 \pm 0.05$ & $0.44 \pm 0.09$ & $-796 \pm 425 \%$ \\
Iron & $\mathrm{mg} \mathrm{L}^{-1}$ & $1.22 \pm 0.37$ & $0.87 \pm 0.3$ & $14 \pm 63 \%$ \\
\hline
\end{tabular}


than before use $(0.23 \mathrm{~g} \mathrm{Zn} / \mathrm{kg}$ of BFM before utilization $\mathrm{Vs} 1.06 \mathrm{~g}$ $\mathrm{Zn} / \mathrm{kg}$ of BFM after utilization). These results were not consistent with the hypothesis of $\mathrm{Zn}$ release during biofiltration process. However, $\mathrm{Zn}$ accumulation in the BFM might occur during the acclimation period (40 days) when the biofilter was fed with the raw landfill leachate that contained an average $\mathrm{Zn}$ concentration of $1.4 \pm 0.6 \mathrm{mg} \mathrm{L}^{-1}$. Thereafter, when the ECLL (containing low $\mathrm{Zn}$ concentration, $0.07 \mathrm{mg} \mathrm{L}^{-1}$ ) was treated by the BF unit, the accumulated $\mathrm{Zn}$ was then released causing higher $\mathrm{Zn}$ concentration at the outlet. The release of $\mathrm{Zn}$ might be also explained by the phenomenon of cations exchange during the filtration. According to Tipping (1998), the complexes formed by $\mathrm{Zn}^{2+}$ with the humic substances are less stable than those formed by $\mathrm{Al}^{3+}$ or $\mathrm{Fe}^{3+}$. The complexes stability constants ( $\log \mathrm{K}_{\mathrm{MA}}$ ) of $\mathrm{Zn}^{2+}, \mathrm{Al}^{3+}$ and, $\mathrm{Fe}^{3+}$ with fulvic acids are 1.6, 2.5 and, 2.4 respectively. In addition, Kerndorff and Schnitzer (1980) investigated the competitive sorption of 11 metals on humic acids and found that the adsorption of $\mathrm{Zn}^{2+}$ was lower than adsorption of $\mathrm{Al}^{3+}$ or $\mathrm{Fe}^{3+}$. As a result, the adsorbed zinc might be substituted by the aluminum and iron ions having stronger affinity with peat mainly comprised of humic substances. This can also explain why $\mathrm{Fe}$ and $\mathrm{Al}$ were better removed than $\mathrm{Zn}$ in spite of their relatively high concentrations in ECLL. In order to avoid the increase of $\mathrm{Zn}$ concentration in the BF outlet, instead of using raw landfill leachate, we recommend the use of electro-coagulated landfill leachate or other types of effluent with low or $\mathrm{Zn}$-free content as inoculum to promote the growth of biomass in biofiltration unit.

\section{Conclusion}

The feasibility of treating landfill leachate by using successively $\mathrm{EC}$ and $\mathrm{BF}$ processes had been investigated. The pretreatment by EC process allowed removing $37 \pm 2 \%$ of the total COD. The fractionation of the organic matter (before and after EC treatment) indicated that the fraction of COD removed from raw landfill leachate was mainly attributed to the removal of insoluble COD and HA. However, the removal of other dissolved organic compounds such as FA and Hyl compounds was relatively low. Furthermore, other pollutants such as turbidity, true color, zinc, and phosphorus were successfully removed (removal of $82 \pm 2.7 \%$, $60 \pm 13 \%$, $95 \pm 2.6 \%$ and $82 \pm 5.5 \%$, respectively). The subsequent biological treatment allowed removing the ammonia pollution as well as a partial fraction of the dissolved organic matter. Over $99 \%$ of the initial $\mathrm{NH}_{4}$ had been removed and nitrate was the main nitrogen by-product formed from the nitrification process. Surprisingly, the phosphorus deficiency and the residual aluminum ions in the electrocoagulated landfill leachate had no negative impact on the nitrification. This can be explained by the recycling of phosphorus from the biomass decay and the $\mathrm{Al}$ ions complexation by humic substances which alleviate their toxicity effect on the microorganisms. The average COD and BOD removals after the biofiltration were 42 $\pm 7 \%$ and $97 \%$ respectively. According to these results, it can be concluded that the EC/BF hybrid process is a promising technology for landfill leachate. The complementarity of these two technologies allows an efficient removal of various range of pollutants found in landfill leachate effluent. However, more research efforts are needed in terms of EC reactor design in order to facilitate its integration in a continuous treatment system and limit the electrodes fouling caused by the raw landfill leachate. This hybrid process is also economically viable. The operating cost of the process had been estimated at around $1.23 \mathrm{US}^{-3}$ which is below the operating cost of most alternative processes used for landfill leachate treatment. This cost takes account the aeration of the biofilter, the renewal of anode material and bio-filter media, the energy consumption and the EC sludge treatment.

\section{Acknowledgement}

This research project was conducted in collaboration with the research institutes INRS - Canada (Institut National de la Recherche Scientifique) and CRIQ (Centre de Recherche Industrielle du Québec) and the companies E2Metrix and Gesterra. It also received the financial support of Mitacs - Canada (IT03162).

\section{References}

APHA, 1998. Standard Methods for the Examination of Water and Wastewater American Public Health Association (APHA), Washington, DC, U.S.A..

APHA, 2005. Standard Methods for the Examination of Water and Wastewater American Public Health Association (APHA), Washington, DC, U.S.A.

APHA, 2012. Standard Methods for the Examination of Water and Wastewater American Public Health Association (APHA), Washington, DC, U.S.A..

Aubry, G., 2008. Étude du comportement de l'azote dans un biofiltre à lit ruisselant traitant du lisier de porc, Département Génie civil. Département Génie civil, Faculté des sciences et de génie. Université Laval, Québec, Canada.

Bouhezila, F., Hariti, M., Lounici, H., Mameri, N., 2011. Treatment of the OUED SMAR town landfill leachate by an electrochemical reactor. Desalination 280, 347353.

Dia, O., Drogui, P., Buelna, G., Dubé, R., 2017. Strategical approach to prevent ammonia formation during electrocoagulation of landfill leachate obtained from a biofiltration process. Sep. Purif. Technol. 189, 253-259.

Dima, G.E., Beltramo, G.L., Koper, M.T.M., 2005. Nitrate reduction on single-crystal platinum electrodes. Electrochim. Acta 50, 4318-4326.

Drogui, P., Blais, J.-F., Mercier, G., 2007. Review of electrochemical technologies for environmental applications. Recent Pat. Eng. 1, 257-272.

Garzón-Zúñiga, M., Lessard, P., Aubry, G., Buelna, G., 2005. Nitrogen elimination mechanisms in an organic media aerated biofilter treating pig manure. Environ. Technol. 26, 361-372.

Hall, E.S., Packham, R.F., 1965. Coagulation of organic color with hydrolyzing coagulants. J. Am. Water Works. Ass. 57, 1149-1166.

Huo, S., Xi, B., Yu, H., He, L., Fan, S., Liu, H., 2008. Characteristics of dissolved organic matter (DOM) in leachate with different landfill ages. J. Environ. Sci. 20, 492 498.

Huo, S.L., Xi, B.D., Yu, H.C., Liu, H.L., 2009. Dissolved organic matter in leachate from different treatment processes. Water Environ. J. 23, 15-22.

Ilhan, F., Kurt, U., Apaydin, O., Gonullu, M.T., 2008. Treatment of leachate by electrocoagulation using aluminum and iron electrodes. J. Hazard. Mater. 154 381-389.

Iversen, V., Koseoglu, H., Yigit, N.O., Drews, A., Kitis, M., Lesjean, B., Kraume, M., 2009. Impacts of membrane flux enhancers on activated sludge respiration and nutrient removal in MBRs. Water Res. 43, 822-830.

Kerndorff, H., Schnitzer, M., 1980. Sorption of metals on humic acid. Geochim. Cosmochim. Acta 44, 1701-1708.

Koukal, B., Gueguen, C., Pardos, M., Dominik, J., 2003. Influence of humic substances on the toxic effects of cadmium and zinc to the green alga Pseudokirchneriella subcapitata. Chemosphere 53, 953-961.

Kurniawan, T.A., Lo, W.H., Chan, G.Y., 2006. Physico-chemical treatments for removal of recalcitrant contaminants from landfill leachate. J. Hazard. Mater. 129, 80-100.

Labanowski, J., Pallier, V., Feuillade-Cathalifaud, G., 2010. Study of organic matter during coagulation and electrocoagulation processes, application to a stabilized landfill leachate. J. Hazard. Mater. 179, 166-172.

Lees, E.J., Noble, B., Hewitt, R., Parsons, S.A., 2001. The impact of residual coagulant on the respiration rate and sludge characteristics of an activated microbial biomass. Process Saf. Environ. Prot. 79, 283-290.

Liu, Z., Wu, W., Shi, P., Guo, J., Cheng, J., 2015. Characterization of dissolved organic matter in landfill leachate during the combined treatment process of air stripping, Fenton, SBR and coagulation. Waste Manage. 41, 111-118.

Mandal, P., Dubey, B.K., Gupta, A.K., 2017. Review on landfill leachate treatment by electrochemical oxidation, drawbacks, challenges and future scope. Waste Manage. 69, 250-273.

MDDELCC, 2009. Règlement sur l'enfouissement et l'incinération des matières résiduelles (REIMR). <http://www.legisquebec.gouv.qc.ca/fr/ShowDoc/cr/Q-2\% 20r.\%2019> (accessed 24.11.16).

Nordeidet, B., Rusten, B., Ødegaard, H., 1994. Phosphorus requirements for tertiary nitrification in a biofilm. Water Sci. Technol. 29, 77-82.

Oumar, D., Patrick, D., Gerardo, B., Rino, D., Ihsen, B.S., 2016. Coupling biofiltration process and electrocoagulation using magnesium-based anode for the treatment of landfill leachate. J. Environ. Manage. 181, 477-483.

Philips, S., Rabaey, K., Verstraete, W., 2003. Impact of iron salts on activated sludge and interaction with nitrite or nitrate. Bioresource Technol. 88, 229-239.

Poveda, M., Yuan, Q., Oleszkiewicz, J., 2016. The effectiveness of pretreatment methods on COD and ammonia removal from landfill leachate. Int. J. Environ. Sci. Dev. 7, 257.

Renou, S., Givaudan, J.G., Poulain, S., Dirassouyan, F., Moulin, P., 2008. Landfill leachate treatment, review and opportunity. J. Hazard. Mater. 150, 468-493.

Smoczyński, L., Muńska, K.T., Kosobucka, M., Pierożyński, B., 2014. Phosphorus and COD removal from chemically and electrochemically coagulated wastewater. Environ. Protect. Eng. 40. 
Snyman, H.G., Rëssle, W., Thompson, A., 1996. The effect of contaminating aluminum sulphate in wastewater sludge production and microbial activity. In: Biennial Conference and Exhibition of the Water Institute of Southern Africa, 4-7 May, Cape Town, pp. 1-8.

Stevenson, F.J., 1994. Humus Chemistry, Genesis, Composition, Reactions. John Wiley \& Sons.

Tipping, E., 1998. Humic ion-binding model VI, an improved description of the interactions of protons and metal ions with humic substances. Aquatic Geochem. 4, 3-47.

Tyagi, R., Couillard, D., 1988. Toxic effects of inhibitors in biological wastewater treatment processes. Can. J. Chem. Eng. 66, 97-106.

USEPA, 1979a. Methods for chemical analysis of water and wastes. Method 350.1. USEPA, 1979b. Methods for chemical analysis of water and wastes. Method 353.1.
Van Zomeren, A., Comans, R.N., 2007. Measurement of humic and fulvic acid concentrations and dissolution properties by a rapid batch procedure. Environ. Sci. Technol. 41, 6755-6761.

Vanhooren, H., 2002. Modelling for optimisation of biofilm wastewater treatment processes, a complexity compromise (Ph.D. Thesis). Universiteit Gent, Belgium.

Wiszniowski, J., Robert, D., Surmacz-Gorska, J., Miksch, K., Weber, J., 2006. Landfill leachate treatment methods, a review. Environ. Chem. Lett. 4, 51-61.

Wu, Y., Zhou, S., Ye, X., Chen, D., Zheng, K., Qin, F., 2011. Transformation of pollutants in landfill leachate treated by a combined sequence batch reactor, coagulation, Fenton oxidation and biological aerated filter technology. Process Saf. Environ. Prot. 89, 112-120.

Xiao, S., Peng, J. Song, Y, Zhang, D, Liu, R., Zeng, P., 2013, Degradation of biologically treated landfill leachate by using electrochemical process combined with UV irradiation. Sep. Purif. Technol. 117, 24-29. 